\title{
UNDANG-UNDANG PORNOGRAFI DALAM TINJAUAN POLITIK HUKUM PIDANA
}

\author{
Oleh: Mufti Khakim \\ Fakultas Hukum Universitas Ahmad Dahlan \\ E-mail: mufti.khakim@law.uad.ac.id
}

\begin{abstract}
Advances in technology has a big contribution in the spread of pornography, even it has a considerable advantage for the business of pornography. On the other hand, emerging social restless and the government will also impact negatively on pornography especially with regards to the mentality of the young generation. Nowadays, pornography can be enjoyed by all people start from children to the elders by the help of technology it makes easier for people to access this site.

The offenses of pornography set in Law Number 44 of 2008 was full of controversy even after have been set, it still reap the rejection of the society. The Government considers that it is time for pornography to regulate specifically so it will not cause restless in the community even though it's been many laws offering pornography. Dangers of pornography take a big part in the mental damage of the young generation it becomes a specific reason why this case needs to be set firmly.

In the politics of criminal law view, it is necessary to study in-depth whether the government's action to regulate pornography in a special law by imposing criminal sanctions are appropriate with the prospects of the people. Regulation of pornography needs to be completed perfectly or it will be better if the regulation be eliminated completely. Conclusions taking technique of this study is using deductive analysis.
\end{abstract}

Keyword: The Politics of Law, Criminal Law, Pornography Law, Pornography

\section{A. LATAR BELAKANG}

Perkembangan pornografi semakin maju seiring dengan kemajuan ilmu dan teknologi. Tingkat penyebaran makin mudah dan meluas serta bebas masuk dalam ruang-ruang privat yang seharusnya steril dari pornografi. Daya rusak pornografi ma-kin masif dan bisnis pornografi makin menjamur dengan memanfaatkan kemajuan teknologi. Penyerangan pornografi terhadap nilai kesusilaan dirasakan makin mem-bahayakan tatanan sosial masyarakat. Kerusakan generasi penerus bangsa makin me-luas terutama generasi muda.

Pornografi menjadi bagian dari salah satu persoalan masyarakat yang harus ditanggulangi dan diselesaikan. Pornografi memiliki dampak negatif yang cukup besar di masyarakat khususnya dalam perkembangan generasi muda. Perbuatan pornografi dianggap sebagai ancaman dalam tatanan sosial masyarakat Indonesia, terutama dalam pembentukan nilai-nilai moral, etika, akhlak mulia, dan kepribadian luhur bangsa.

Pro kontra bermunculan saat pornografi akan diatur dalam bentuk undangundang sebagai solusi dari persoalan yang muncul akibat dari perkembangan 
pornog-rafi yang tidak terkendali. Perdebatan dimulai dari pengertian tentang pornografi, ap-akah pornografi akan dikriminalkan? Apakah perlu undang-undang tersendiri yang mengatur khusus tentang pornografi? Bahkan ada anggapan hal ini cukup diatur dalam Kitab Undang-Undang Hukum Pidana (KUHP). Ada beberapa peraturan yang juga mengatur tentang pornografi dan dianggap sudah mengakomodasi tentang pe-ngaturan pornografi.

Undang-undang no 44 tahun 2008 memberikan definisi tentang pornografi sesuai dengan Pasal 1 ayat 1 adalah gambar, sketsa, ilustrasi, foto, tulisan, suara, bunyi, gambar bergerak, animasi, kartun, percakapan, gerak tubuh, atau bentuk pesan lainnya melalui berbagai media komunikasi dan/atau pertunjukan di muka umum, yang memuat kecabulan atau eksploitasi seksual yang melanggar norma kesusilaan dalam masyarakat.

Sebagian pandangan yang lain merasa sudah saatnya undang-undang pornografi dibuat dalam undang-undang tersendiri dengan alasan Kitab Undangundang Hukum Pidana yang sekarang dan undang-undang yang terkait dianggap tumpul da-lam penanganan kejahatan yang berkaitan dengan pornografi.

Akibat dari pro dan kontra tentang perlu tidaknya pornografi diatur dalam undang-undang tersendiri membuat waktu yang diperlukan untuk membahas dan mengesahkannya perlu waktu sampai 10 tahun. Hal ini menandakan betapa dinamis-nya tarikan kepentingan dan perdebatan, antar pihak, baik partai politik maupun masyarakat yang harus diakomodir. Apakah undang-undang ini sudah sesuai dengan keinginan masyarakat atau sebaliknya malah menimbulkan persoalan baru dalam masyarakat maupun dalam penegakkanya. Atas dasar tersebut muncul beberapa per-tanyaan, yaitu apa latar belakang filosofis, sosialogis, dan politik pembentukan Un-dang-undang Pornografi dan apakah undang-undang No 44 Tahun 2008 dalam tinjau-an politik hukum Pidana Indonesia sudah tepat dan benar?

\section{B. METODE PENELITIAN}

Penelitian ini merupakan penelitian normatif yaitu meneliti dengan mengkaji, menganalisa sumber data sekunder yang berupa buku-buku teks, dokumen tertulis, serta hasil penelitian terdahulu. Penelitian hukum normatif mencakup penelitian ter-hadap asas-asas hukum, penelitian terhadap sistematika hukum, penelitian terhadap sinkronisasi vertikal dan horizontal perbandingan hokum, dan sejarah hukum. Pene-litian ini menggunakan empat (4) pendekatan hukum yaitu: Pendekatan yuridis, Pen-dekatan kebijakan, dan Pendekatan nilai.

Analisis data dengan menggunakan analisis kualitatif yaitu analisis yang menguraikan data penelitian menjadi komponen melalui rangkaian kata-kata dan atau gambar. Pengkajian Undang-Undang no 44 Tahun 2008 dimulai dari penelitian nilai filisofis, sosiologis dan pembentukan hukum kemudian dengan menggunakan teori-teori tentang politik hukum pidana sebagai pisau analisis untuk mencari apakah langkah Negara mengatur pornografi dengan sanksi pidana sudah tepat atau 
belum. Analisis kualitatif lebih menekankan analisis terhadap kualitas data daripada kuan-titas data itu sendiri. Kesimpulan diambil dengan cara deduktif yaitu menyimpulkan dari suatu yang bersifat umum ke dalam hal-hal yang bersifat khusus.

\section{KERANGKA TEORI}

\section{Politik Hukum \& Politik Hukum Pidana}

Politik hukum terdiri dari dua kata yaitu politik dan hukum, menurut Sudarto istilah politik sering dipakai dalam berbagai arti yaitu: politeik dalam Bahasa Belanda berarti sesuatu yang berhubungan dengan Negara dan yang kedua politik berarti membicarakan masalah kenegaraan atau yang berhubungan dengan negara. Sudarto juga memberikan makna lain dari politik, yaitu kebijakan yang merupakan sinonim dari policy (Teguh Prasetyo, 2005: 10).

Politik hukum yang akan atau telah dilaksanakan secara nasional oleh pemerintah; mencakup pula pengertian tentang bagaimana politik mempengaruhi hukum dengan cara melihat konfigurasi kekuatan yang ada di belakang pembuatan dan pene-gakan hukum itu. Hukum tidak dapat hanya dipandang sebagai pasal-pasal yang ber-sifat imperatif atau keharusan-keharusan, melainkan harus dipandang sebagai sub-sistem yang dalam kenyataan bukan tidak mungkin sangat ditentukan oleh politik, baik dalam perumusan materi dan pasal-pasalnya, maupun dalam implementasi dan penegakkannya

Menurut G. Peter Hoefnagels politik hukum pidana adalah suatu usaha yang rasional dari masyarakat dalam rangka menanggulangi tindak pidana (Teguh Prasetyo dan Abdul Barkatullah, 2005: 13). Hal ini memberikan pengertian bahwa politik hukum pidana diharuskan dilakukan dengan penuh pertimbangan yang rasional bu-kan emosional karena politik hukum pidana adalah proses pemilihan hukum yang akan diterapkan dalam masyarakat dalam mencapai cita-cita masyarakat sehingga pilihan harus dapat dipertanggungjawabkan.

Politik hukum pidana adalah bagian dari politik hokum, maka dalam pemben-tukan undang-undang harus mengetahui sistem nilai yang berlaku dalam masyarakat. Menurut Soedarto jika hukum pidana mau dilibatkan dalam politik hukum, maka ha-rus melihat secara keseluruhan hubungan antara kebijakan nasional dan kebijakan hukum secara luas. Ini dilakukan agar tidak terjadi ketimpangan antara kebijakan hu-kum pidana dengan kebijakan hukum nasional (Barda Nawawi, 2011: 26).

Kebijakan hukum pidana adalah suatu upaya untuk menanggulangi tindak pi-dana, di samping ada upaya lain yaitu penanggulangan dengan menggunakan kebija-kan non penal. Politik hukum pidana bersifat represif setelah terjadinya suatu tindak pidana. Marc Ancel memberikan pendapat bahwa politik hukum pidana atau kebija-kan hukum pidana merupakan suatu ilmu sekaligus seni yang mempunyai tujuan praktis untuk memungkinkan peraturan hukum positif dirumuskan secara 
lebih baik dan untuk memberi pedoman kepada pembuat undang-undang, dan kepada para pe-laksana putusan pengadilan (Teguh Prasetyo dan Abdul Halim Barkatullah, 2005: 18).

Pada intinya politk hukum pidana adalah bagaimana hukum pidana dapat dirumuskan dengan baik dan memberikan pedoman kepada pembuat undang-undang (kebijkaan legislatif), kebijakan aplikasi (kebijakan yudikatif) dan pelaksana hukum pidana (kebijakan eksekutif). Barda Nawawi menekankan bahwa dalam pemilihan hukum pidana digunakan sebagai penanggulangan kejahatan maka politik hukum pi-dana harus dilakukan secara sadar dan sengaja. Perhitungan-perhitungan semua fak-tor harus cermat sehingga politik hukum pidana bisa dilaksanakan dan dapat bekerja sebagaimana yang diharapakan.

\section{Dasar Pijakan Politik Hukum}

Ada empat hal yang menjadi basis dalam menentukan dasar pijakan menentukan politik hukum, yaitu (Bernard L. Tanya, 2011: 13-35):

a. Pertama basis ideologi

Basis ideologi yang berupa nilai-nila dasar yang dianut oleh suatu bangsa. Ideologi adalah seperangkat nilai, ide, cita, visi suatu bangsa yang diyakini akan bisa mengantarkan suatu bangsa sesuai dengan apa yang dicitakan. Politik hukum diarahkan oleh idoelogi, jadi ideolog juga berfungsi sebagai leistern (bintang penuntun) bagi terwujudnya visi yang ingin diraih. Ma-sing-masing negara memiliki ideologi yang berbeda-beda sehingga politik hukumnya berbeda. Ada Negara dengan basis ideologi liberal, kapitalis, sosialis atau lainya sedangkan Indonesia memiliki basis ideolo-gi yaitu Pancasila. Sebagai idoeologi Negara Indonesia, maka Pancasila di-jadikan sebagai arah politik hukum bangsa Indonesia.

b. Kedua basis Normatif

Basis ini merupakan penjabaran dari basis ideologi, basis normatif berupa kerangka normatif bagi politik hukum. Basis normatif menjadi dasar penilaian apa yang seharusnya tentang nilai baik, buruk, adil, dan lainlain. Hal ini agar sebelum melakukan politik hukum diketahui lebih dahulu mana yang salah dan mana yang benar, mana yang adil dan mana yang tidak adil, mana yang baik dan mana yang tidak baik baru kemudian akan diambil keputusan.

c. Ketiga basis konstitusional

Basis ini merupakan dasar pengambilan keputusan tentang politik hukum. Konstitusi memberikan arah dan tujuan suatu bangsa. Konstitusi juga sebagai pembatas kekuasaan dan sekaligus pengatur kekuasaan dan juga sebagai penjamin terpenuhinya hak-hak warga Negara.

d. Kempat Basis moral

Basis ini sangat diperlukan dalam politik hukum karena kebijakan yang mutu dan berorientasi pada perubahan bagi kepentingan orang banyak 
hanya bisa lahir dari lembaga/pengambil keputusan yang memiliki tingkat kesadaran moral yang mumpuni.

\section{Dasar Pembenaran Kriminalisasi}

Penentuan perbuatan yang dijadikan tindak pidana mempunyai hubungan yang erat dengan masalah "kriminalisasi". Kriminalisasi yaitu proses untuk menjadikan suatu perbuatan yang semula bukan tindak pidana menjadi tindak pidana. Proses kriminalisasi tersebut diakhiri dengan terbentuknya peraturan perundangundangan di mana perbuatan tersebut diancam dengan suatu sanksi berupa pidana. Terbentuk-lah peraturan hukum pidana yang siap untuk diterapkan oleh hakim, dan selanjutnya apabila dijatuhkan pidana, dilaksanakan oleh kekuasaan administratif (Soedarto, 2007: 32)

Terkait dengan pandangan kriminalisasi sebagai sebuah kebijakan, Basioni berpendapat dalam bukunya IS Heru Permana bahwa sebenarnya dalam mengkrimi-nalisasikan suatu perbuatan dilatar belakangi oleh tujuan yang ingin dicapai dengan kebijakan tersebut (Is Heru Permana, 2007: 30). Misalnya adalah adanya kepenti-ngan-kepentingan sosial yang mengandung nilai-nilai tertentu

Proses kriminalisasi harus didasarkan pada landasan teori keilmuan yang bisa dipertanggungjawabkan, di mana dalam hal ini ada beberapa teori yang digunakan sebagai dasar pembenaran kriminalisasi perbuatan pornografi.

Pertama, yaitu teori moral yang memiliki peran penting dalam pembentukan hukum pidana. Moral merupakan salah satu sumber nilai bagi pembentukan hukum pidana. Sebagai kaidah hukum pidana yang mengatur tentang kejahatan (tindak pidana) berasal dari kaidah-kaidah moral yang hidup dalam masyarakat (Salman Luthan, 2007: 72). Perbuatan yang melanggar moral melalui kebijakan hukum pidana yaitu proses legislasi yang kemudian diundangkan menjadi undang-undang. Max We-ber mengatakan bahwa hukum harus mengekpresikan suatu moralitas umum ( $a$ com-mon morality) yang didasarkan pada suatu konsensus tentang apa yang secara moral dianggap salah dan apa yang secara moral dianggap benar (Achmad Ali, 2007: 72).

Hart mengidentifikasikan empat ciri pokok yang selalu ditemukan bersamasama dalam setiap aturan dan standar prilaku yang biasa disebut moral, yaitu nilai penting (importance), kekebalan dari perubahan yang disengaja, ciri kesengajaan da-lam pelanggaran moral, dan bentuk tekanan moral (Petrus C.K.L Bello, 2012: 41).

Kedua, yaitu Teori Liberal Individualistik. Teori ini merupakan antitesis dari teori moral. Teori ini berpandangan bahwa kriminalisasi suatu perbuatan janganlah didasarkan pada landasan pertimbangan-pertimbangan moral akan tetapi didasarkan pada ada tidaknya kerugian dari perbuatan tersebut (Salman Luthan: 2007: 82). Mild menegaskan bahwa kekuasaan Negara untuk mengatur masyarakat dibatasi oleh kebebasan warganegara. Negara boleh ikut campur tangan terhadap kehidupan pribadi warganegara bila warganegara tersebut merugikan kepentingan orang lain. Jika tindakan seseorang tidak merugikan orang lain maka tidak boleh ada 
pembatasan terhadap kebebasannya (Salman Luthan, 2007: 83). Ketiga, yaitu Teori Feinberg. Feinberg mengajukan dua alasan sebagai dasar kriminalisasi, yaitu (Salman Luthan, 2007: 97):

1. Kriminalisasi dalam rangka mencegah atau mengurangi kerugian kepada orang lain.

2. Kriminalisasi dalam rangka mencegah serang-serangan serius kepada orang lain untuk mencegah atau mengurangi

Keempat, yaitu teori "Ordeningstrafrecht". Toeri ini menyatakan bahwa hukum pidana adalah alat atau instrumen pemerintah. Penggunaan hukum pidana seba-gai instrumen kebijakan pemerintah merupakan kecenderungan baru dalam perkem-bangan hukum pidana modern (Salman Luthan, 2007: 106).

Peneliti akan menggunakan teori Moral untuk menganalisis apakah krimininalisasi pornografi sudah tepat atau belum. Peneliti memilih teori ini karena kiranya tepat pornografi dilihat dari sisi teori Moral karena pornografi pada intinya adalah persoalan moralitas kesusilaan.

\section{PEMBAHASAN}

\section{Latar Belakang Filosofis}

Salah satu kekuatan undang-undang atau norma adalah adanya kekuatan landasan filosofis. Undang-undang Pornografi berakar dari keinginan besar mewujudkan Indonesia sebagai negara hukum yang berlandaskan Pancasila dengan men-junjung tinggi nilai-nilai moral, etika, akhlak mulia, dan kepribadian luhur bangsa, beriman dan bertakwa kepada Tuhan yang Maha Esa, menghormati kebinekaan da-lam kehidupan bermasyarakat, berbangsa dan bernegara serta melindungi harkat dan martabat setiap warga Negara.

Undang-undang pornografi hadir dalam rangka ingin melindungi kepentingan hukum yang berkaitan dengan rasa kesusilaan baik rasa kesusilaan pribadi maupun rasa kesusilaan masyarakat. Masyarakat memiliki nilai-nilai kesusilaan yang hidup dan dijunjung tinggi oleh masyarakat dan karena itu harus dipatuhi. Nilai-nilai yang hidup dalam diri individu dan masyarakat menjadi cerminan sifat dan karakter dari suatu lingkungan masyarakat bahkan suatu bangsa. Patokan patut dan tidak patutnya suatu perbuatan, dianggap menyerang atau tidak terhadap kepentingan hukum me-ngenai rasa kesusilaan tidak semata-mata bersifat individual tetapi ada juga nilai-nilai universal (Adam Cahzawi, 2013: 6). Nilai kesusilaan hadir dilandasi oleh nilai agama, budaya, adat istiadat norma-norma lain yang diyakini oleh masyarakat. Keterusikan nilai kesusilaan berdampak pada rasa ketentraman batin terganggu.

\section{Latar Belakang Sosiologis}


Undang-undang pornografi memiliki latar belakang sosiolgis yang mengakar karena sebenaranya persoalan ini sudah diatur dalam KUHP (Kitab Undang-Undang Hukum Pidana) dengan delik kesusilaan. Seiring perubahan waktu, delik kesusilaan mengalami perubahaan sejalan dengan kemajuan tekhnologi informasi. Media yang digunakan menjadi beragam terutama dengan adanya internet di mana setiap orang begitu mudah untuk mengakses pornografi. Pornografi tidak lagi semata-mata disebarkan di muka umum dengan cara ditempelkan di tempat umum atau lewat majalah, koran, selebaran, bulletin, akan tetapi melalui dunia maya. Pelaku tindak pidana por-nografi juga tidak semudah dahulu untuk secepatnya dideteksi siapa pelakunya, se-hingga KUHP tidak lagi bisa menjangkau.

Sikap masyarakat terhadap pornografi mengalami pertarungan yang hebat, di satu sisi masyarakat Indonesia ingin melindungi generasi muda dan anak-anak dari kemerosotan moral, tapi di sisi lain tuntuntan liberalisme yang dibawa oleh budaya barat semakin kuat. Tuntutan liberalisme membebaskan hak individu, sampai budaya free sex menjadi sesuatu yang dianggap biasa. Negara barat beranggapan bahwa seks adalah hak pribadi yang semua orang boleh untuk menikmatinya.

\section{Latar Belakang Politik Pembentukan undang-undang Pornografi}

Pembahasan Rancangan Undang-undang Anti Pornografi dan Pornoaksi dimulai sejak tahun 1997. Dalam perjalanannya draf RUU APP pertama kali diajukan pada 14 Februari 2006 dan berisi 11 bab dan 93 Pasal. Pada draf kedua, beberapa Pasal yang kontroversial dihapus sehingga tersisa 82 Pasal dan 8 Bab (wikipedia.org/wiki/Undang-Undang_Pornografi\# Definisi_dan_Rancangan).

Tanggal 24 Agustus 2007 DPR mengirimkan draf kepada presiden tentang RUU APP yang terdiri dari 10 bab dan 52 Pasal. Judul RUU APP dirubah menjadi RUU Pornografi, sementara ketentuan mengenai pornoaksi dihapus. Pada September 2008, Presiden menugaskan Menteri Agama, Menteri Komunikasi dan Informatika, Menteri Hukum dan Hak Asasi Manusia, dan Menteri Negara Pemberdayaan Perempuan untuk membahas RUU ini bersama Panitia Khusus DPR. Pada draf final yang awalnya direncanakan akan disahkan pada 23 September 2008, RUU Pornografi ting-gal terdiri dari 8 bab dan 44 Pasal. Panja telah melaksanakan Rapat pada tanggal 4 September 2008, 18 September 2008, 23 September 2008, 24 September 2008, 8 Oktober 2008, 16 Oktober 2008, 17 Oktober 2008, 22 Oktober 2008, 23 Oktober 2008, 27 Oktober 2008, dan 28 Oktober 2008 (wikipedia.org/wiki/UndangUndang_Pornografi\# Definisi_da n_Rancangan.)

Proses pengesahan Undang-undang pornografi mengalami masa-masa yang cukup dramatis. Aksi walk out yang dilakukan oleh dua fraksi yaitu PDIP (Partai Demokrasi Indonesia Perjuangan) dan PDS (Partai Demokrasi Sejahtera) memberikan gambaran betapa secara politik gesekan yang terjadi cukup keras. Walk out PDIP dengan alasan sebagai berikut (risalah sidang paripurna DPR RI, 30 Oktober 2008), bahwa pertama, fraksi PDIP merasa prihatin dengan kondisi masyarakat dan daerah yang makin terbelah dengan adanya rencana Undang-Undang Pornografi. Kedua, be- 
lum adanya treatment khusus dari pansus dan emerintah untuk bisa menjelaskan hal-hal yang lebih baik daripada kondisi sekarang ini. Selanjutnya secara prosedural dan secara substansial ada hal-hal yang oleh Fraksi PDIP tidak setuju. Ketiga, pada prin-sipnya, Fraksi PDIP mendukung upaya pengaturan yang menyangkut pornografi ka-rena dampaknya akan merusak kejiwaan anak-anak. Tetapi secara prosedural dan se-cara substansial ada hal-hal yang tidak cocok dengan Rancangan Undang-undang ini, sehingga fraksi PDIP tidak ikut bertanggungjawab, tidak ikut dalam proses pengambi-lan keputusan pada paripurna hari ini dan memutuskan walk out. Sedangkan dari FPDS (Fraksi Damai Sejahtera) berpandangan bahwa setelah melihat rapat bamus yang sudah dilakukan, di mana dua fraksi menolak dan satu meminta menunda, maka FPDS meminta untuk menunda pengesahan karena banyak protes. FPDS menghen-daki agar rapat memanggil dulu dua daerah yang menolak Undang-Undang Pornog-rafi ini yaitu Bali dan Sulawesi Utara. FPDS menolak Rancangan Undang-Undang Por-nografi jika disahkan dan akhirnya walk out. Secara kuantitatif, kekuatan untuk meng-golkan RUU Pornografi di parlemen, baik itu kekuatan pendukung dan penolakan ada-lah 428 mendukung yang terdiri dari: Fraksi Golkar 129 kursi, PPP 58 kursi, Partai Demokrat 57 kursi, PAN 53 kursi, PKB 52 kursi, PKS 45 kursi, BPD 20 kursi, dan PBR 14 kursi. Sedangkan kekuatan anggota parlemen yang menolak sebanyak 122 kursi, diwakili dua Fraksi, yaitu Partai Demokrasi Indonesia Perjuangan (PDIP) sebanyak 109 kursi dan PDS sebanyak 13 kursi.

\section{Pornografi dalam Tinjauan Politik Hukum Pidana}

Undang-Undang tentang Pornografi yaitu undang-undang no 44 tahun 2008 adalah salah satu dari politik hukum pidana yang diambil oleh para pembentuk undang-undang. Pilihan kebijakan politik hukum dengan menggunakan hukum pidana untuk menanggulangi tindak pidana pornografi tentunya harus memenuhi prinsipprinsip pengambilan kebijakan politik hukum.

Hal mendasar yang harus dijawab adalah apakah politik hukum menggunakan hukum pidana untuk menangani persoalan pornografi sudah memiliki dasar pijakan politik hukum sesuai dengan prinsip-prinsip politik hukum? Pijakan dasar pertama adalah pijakan ideologi, ideologi dimaknai sebagai nilai-nilai sentral dan hakiki dan atas dasar itu kita mengadakan penilaian dan perbaikan atas segala sesuatu yang lain dalam kehidupan kita. Steeman menegaskan bahwa nilai adalah sesuatu yang dijun-jung tinggi, sesuatu yang memberi makna kepada hidup yang memberi kepada hidup ini titik-tolak, isi dan tujuan. Ideologi yang dimaksud juga sebagai sistem makna yang memberikan arahan atau petunjuk politik hukum akan diarahkan (Bernard L. Tanya, 2011: 13).

Pancasila sebagai ideologi dalam kehidupan bernegara menjadi dasar bagi landasan politik hukum Bangsa Indonesia. Pancasila berbeda dengan paham liberal, sosialis atupun ideologi kapitalis. Pancasila mengedepankan keseimbangan antara pemenuhan hak pribadi dan hak publik, jasmani dan rohani. Ini tercermin dalam sila-sila yang terkandung di dalamnya. Sila pertama "Ke-Tuhanan Yang Maha Esa" 
mem-berikan makna bahwa Bangsa Indonesia adalah bangsa yang berke-Tuhanan, bangsa yang meyakini adanya kebenaran yang hakiki, Tuhan sebagai sumber kebenaran. Nilai yang muncul adalah bahwa produk politik hukum harus mencerminkan nilai Ke-Tuhanan. Benar dan tidaknya produk hukum harus pula dikaitkan dengan kebenaran Tuhan yang tercermin dalam bentuk ajaran agama. Bangsa Indonesia tidak bisa hidup sebebas-bebasnya karena telah dibingkai oleh nilai ke-Tuhanan. Undang-Undang Pornografi kalau mau ditilik dari basis ideologi jelas tidak bertentangan dengan nilai ke-Tuhanan bahkan sebaliknya pornografi bertentangan dengan nilai ke-Tuhanan yang diyakini oleh bangsa Indonesia. Tuhan menciptakan manusia sebagai makhluk yang bermartabat, maka perilaku manusia yang merendahkan martabat kemanusia-an itu sendiri secara tidak langsung bertentangan dengan sila pertama.

Sila kedua dari Pancasila lebih menegaskan lagi, seperti apa sebenarnya manusia Indonesia yang ingin dibentuk oleh ideologi Pancasila, yaitu Kemanusiaan yang Adil dan Beradab. Makna dari sila kedua menyiratkan bahwa Bangsa Indonesia adalah bangsa yang berperikemanusiaan dan berperadaban, bangsa yang menjunjung tinggi nilai-nilai luhur budaya tetapi juga beradab. Pornografi jelas suatu tindak yang me-rendahkan nilai-nilai kemanusiaan yang berperadaban. Manusia sebagai makhluk yang berakal dan memiliki rasa malu sudah seharusnya menjaga dari perbuatan-per-buatan yang merendahkan nilai manusia itu sendiri seperti perbuatan cabul, eksploi-tasi seksual, perbuatan yang mengundang nafsu yang tidak seharusnya diumbar se-perti binatang tetapi harus disalurkan dengan jalan yang benar.

Basis pijakan kedua adalah basis normatif. Politik hukum seharusnya mampu memberikan penilaian mana yang seharusnya bukan senyatanya, maka basis norma-tif memberikan penilaian kepada politik hukum apakah sudah adil, benar, salah atau yang lainnya. Basis normatif sebagai penjabaran dari basis ideologi sehingga kedua-nya saling berhubungan dan paralel. Berdasarkan tinjauan ini, maka undang-undang tentang pornografi harus dilihat apakah sudah benar atau tidak menurut nilai kebe-naran yang dianut oleh Bangsa Indonesia, apakah sudah adil menurut nilai keadilan yang dianut oleh Bangsa Indonesia. Undang-Undang Pornografi dikatakan benar ka-lau sudah sesuai dengan normatifitas ideologi Bangsa Indonesia, sebaliknya jika ber-tentangan, maka itu dikatakan salah.

Ketiga undang-undang pornografi dilihat dari basis konstitusional. Konsititusi sebagai barometer dana landasan pijakan dasar hukum yang akan diberlakukan. Kon-stitusi juga memuat tentang tujuan yang akan dicapai dalam kehidupan berbangsa dan bernegara. Undang-Undang Pornografi sudah mengalami masa-masa ujian berat saat dibenturkan dengan konstitusi, yaitu pada waktu baru diberlakukan kemudian diajukan peninjauan kembali yang diajukan oleh sejumlah pihak, baik dari perora-ngan maupun LSM pada tanggal 9 februari 2008, 10 maret 2008, 25 maret 2008 ke Mahkamah Konstitusi. Hal yang dipersoalkan adalah sebagai berikut: 
a. Undang-Undang Pornografi dianggap telah melanggar hak konstitusional pemohon yang terdapat dalam Pasal 28C Undang-undang Dasar 1945 yang berbunyi : "(1) Setiap orang berhak mengembangkan diri melalui pe-menuhan kebutuhan dasarnya, berhak mendapat pendidikan dan mem-peroleh manfaat dari ilmu pengetahuan dan teknologi, seni dan budaya, demi meningkatkan kualitas hidupnya dan demi kesejahteraan umat ma-nusia. (2) Setiap orang berhak untuk memajukan dirinya dalam memper-juangkan haknya secara kolektif untuk membangun masyarakat, bangsa, dan negaranya. Pasal 32 ayat 1 Undang-undang Dasar 1945 yang ber-bunyi: "Negara memajukan kebudayaan nasional Indonesia di tengah per-adaban dunia dengan menjamin kebebasan masyarakat dalam memeliha-ra dan mengembangkan nilai-nilai budayanya".

b. Undang-Undang Pornografi telah melanggar living constitutional values yang terdapat dalam penjelasan Undang-Undang Dasar 1945.

c. Pasal 1 angka 1, Pasal 4 ayat (1) huruf d dan Pasal 10 UU Pornografi bertentangan dengan Pancasila sebagai Staats Fundamental Norm dan Amandemen keempat UUD 1945.

Keputusan Mahakamah Konstitusi menyatakan menolak permohonan pemohon untuk seluruhnya, hal ini berarti bahwa undang-undang pornografi secara basis konstitusional sudah selaras.

Keempat adalah basis dasar pijakan terakhir yaitu basis moral. Undang-Undang Pornografi dilihat dari basis pijakan moral yang bertumpu pada tiga hal yitu moralitas taat asas, moralitas akal kritis, dan moralitas hati nurani. Tindakan pornog-rafi telah senyatanya mengganggu ketentraman batin masyarakat Indonesia, di mana nilai moral ketimuran yang penuh dengan sopan santun dan juga keberadaban dijun-jung tinggi. Rasa ketidak tentraman terhadap nilai moral yang hidup inilah yang men-jadi pijkan dasar dalam menentukan politik hukum. Basis moral juga dibenarkan da-lam teori kriminalisasi di mana suatu tindakan yang bertentangan dengan moral da-pat dikriminalisasikan.

Undang-Undang No 44 Tahun 2008 tentang pornografi ditinjau dari teori poli-tik hukum maka bisa dijelaskan sebagai berikut:

a. Pengaturan pornografi dalam bentuk undang-undang dengan menggunakan sanksi pidana, maka kebijakan tentang mengundangkan pornografi sebagai bagian dari kebijakan hukum pidana. Pengaturan pornografi adalah dalam rangka memenuhi unsur kepastian hukum dan rasa keadilan. Selama ini tindak pornografi tidak diatur secara eksplisit, KUHP menyebut tindak pornografi sebagai tindak kesusilaan, sebagaimana tertulis dalam Pasal 282 dan pasal 283 KUHP untuk Kejahatan. Bab XIV buku II mengatur juga tentang pornografi "kesusilaan" pada pasal 532 KUHP. Kesusilaan memiliki arti sangat luas, secara garis besar, Andi Hamzah me-nerjemahkan kesusilaan dengan "menimbulkan rasa malu seksual" arti ini sangat sederhana tapi cakupannya menjadi luas karena rasa malu seksual sangat tergantung dari agama, budaya, daerah, negara di mana 
pasal ini akan diterapkan (Andi Hamzah: 2011: 156). Undang-Undang No.32/2002 Tentang penyiaran pada pasal 36 ayat 5 point b menggunakan kata "cabul" untuk mewakili kata pornografi. Peraturan tentang pers yaitu Undang-Undang No.40/1999 pada pasal 5 ayat 1 menggunakan kata "kesusilaan". Undang-undang yang ada sebelumnya menggunakan istilah yang berbe-da-beda untuk mewakili kata pornografi. Hal inilah yang menyebabkan multi tafsir dalam penerapannya sehingga tidak ditemui adanya kepastian hokum. Oleh karena itu kiranya sudah tepat kalau ponrografi diatur seca-ra eksplisit dan tidak menimbulkan penafsiran ganda dalam penerapan-nya.

b. Undang-Undang no 44 tahun 2008 tentang pornografi sebagaimana dalam optik Plato maka sebuah undang-undang harus mencantumkan tujuan da-ri undang-undang tersebut. Undang-Undang Pornografi memuat di da-lamnya tujuan dari dibentuknya undang-undang tersebut yaitu yang ter-dapat dalam Pasal 3, yaitu:

1) Mewujudkan dan memelihara tatanan kehidupan masyarakat yang ber-etika, berkepribadian luhur, menjunjung tinggi nilai-nilai Ketuhaan Yang Maha Esa, serta menghormati harkat dan martabat kemanusiaan;

2) Menghormati, melindungi, dan melestarikan nilai seni dan budaya, adat istiadat, dan ritual keagamaan masyarakat Indonesia yang majemuk;

3) Memberikan pembinaan dan pendidikan terhadap moral dan akhlak masyarakat;

4) Memberikan kepastian hukum dan perlindungan bagi warga Negara dari pornografi, terutama bagi anak dan perempuan;

5) Mencegah berkembangnya pornografi dan komersialisasi seks di masyarakat.

c. Undang-Undang Pornografi berkeinginan untuk mewujudkan masyarakat Indonesia sebagai masyarakat yang terdiri dari manusia-manusia yang bermartabat. Manusia yang memiliki peradaban dan manusia yang menghormati nilai-nilai kemanusiaan. Pornografi adalah perbuatan hewani dimana hal yang seharusnya menjadi domain privat kemudian menjadi domain publik, sehingga tidak ada lagi penghormatan kepada manusia sebagai makhluk yang mulia dan menjunjung kemuliaan. Berdasarkan optic ini, maka Undang-Undang Pornografi sudah selaras yaitu mengarahkan manusia menjadi individu yang saleh.

d. Ditinjau dari sudut Politik Hukum Pidana, maka Pengundangan tentang pornografi adalah pilihan yang rasional untuk menanggulangi tindak pornografi yang semakin tidak terkendali. Undang-undang sebelumnya terbukti mandul atau tidak mampu untuk mengantisipiasi tindak pornografi. Keberkembangan pornografi ternyata tidak bisa diikuti oleh undangundang sebelumnya. Oleh kerana itu kiranya tepat pornografi dibuat undang-undang tersendiri dengan menggunakan sanksi pidana. 


\section{E. KESIMPULAN}

Undang-Undang No 44 Tahun 2008 tentang pornografi ditinjau dari teori politik hukum maka bisa dijelaskan sebagai berikut:

1. Pembentukan Undang-undang No 44 Tahun 2008 ditinjau dari sisi filosofis, sosio-logis dan politik hukum sebagai berikut:

a. Secara filosofis Pembentukan Undang-Undang no 44 Tahun 2008 tentang pornografi sangat kuat. Undang-Undang Pornografi berakar dari keinginan besar mewujudkan Indonesia sebagai negara hukum yang berlandaskan Pancasila dengan menjunjung tinggi nilai-nilai moral, etika, akhlak mulia, dan kepribadian luhur bangsa, beriman dan bertakwa kepada Tuhan yang Maha Esa, menghormati kebinekaan dalam kehidupan bermasyarakat, berbangsa dan bernegara serta melindungi harkat dan martabat setiap warga Negara. Undang-Undang Pornografi hadir dalam rangka ingin melindungi kepentingan hukum yang berkaitan dengan rasa kesusilaan baik rasa kesusilaan pribadi maupun rasa kesusilaan masyarakat. Masyarakat memiliki nilai-nilai kesusilaan yang hidup dan dijunjung tinggi oleh masyarakat dan karena itu harus dipatuhi. Nilai-nilai yang hidup dalam diri individu dan masyarakat menjadi cerminan sifat dan karakter dari suatu lingkungan masyarakat bahkan suatu bangsa.

b. Secara sosiologis Undang-Undang Pornografi memiliki latar belakang sosio-logis yang mengakar karena sebenaranya persoalan ini sudah diatur dalam KUHP (Kitab Undang-Undang Hukum Pidana) dengan delik kesusilaan.

c. Secara politik walaupun pada masa pembahasan terjadi tarik menarik anta-ra yang setuju dengan yang tidak setuju, tapi pada kenyataanya kekuatan politik yang setuju lebih besar ketimbang yang tidak setuju. Analisis ke-kuatan untuk menggolkan RUU Pornografi secara perkiraan kuantitatif di parlemen untuk kekuatan pendukung dan penolakan adalah 428 men-dukung, terdiri dari; Fraksi Golkar 129 kursi, PPP 58 kursi, Partai Demokrat 57 kursi, PAN 53 kursi, PKB 52 kursi, PKS 45 kursi, BPD 20 kursi dan PBR 14 kursi. Sedangkan kekuatan anggota parlemen yang menolak sebanyak 122 kursi, terdiri dari Partai Demokrasi Indonesia Perjuangan (PDIP) sebanyak 109 kursi dan PDS sebanyak 13 kursi.

2. Ditinjau dari sudut Politik Hukum Pidana, maka Pengundangan tentang pornografi adalah pilihan yang rasional untuk menanggulangi tindak pornografi yang semakin tidak terkendali. Undang-undang sebelumnya terbukti mandul atau tidak mampu untuk mengantisipiasi tindak pornografi. Keberkembangan pornografi ternyata tidak bisa diikuti oleh undang-undang sebelumnya oleh kerana itu kiranya tepat pornografi dibuat undang-undang tersendiri dengan menggunakan sanksi pidana. Undang undang ini juga sudah memenuhi persyaratan basis pijakan politik hukum yaitu basis ideologi, basis normatif, basis konstitusi dan basis moral. 


\section{DAFTAR PUSTAKA}

\section{BUKU DAN JURNAL}

Ali, Achmad dan Wiwie, Heryani (2007). Menjelajah Kajian Empiris terhadap hokum. Jakarta: Kencana.

Bakhri, Syaiful (2010). Kebijakan Kriminal Dalam Prespektif Pembaruan Sistem Peradilan Pidana Indonesia. Jakarta: Total Media.

Bello Petrus, C.K.L. (2012). Hukum dan Moralitas Tinjauan Filsafat Hukum. Jakarta: Erlangga.

Djubaedah, Neng (2004). Pornografi \& Pornoaksi Ditinjau dari Hukum Islam. Jakarta: Kencana Prenada Media Group.

Firdaus, Syam (2010). Analisis Undang-undang Pornografi. Penelitian Kementrian Hukum dan Hak Asasi Manusia.

Permana, Heru Is (2007). Politik Kriminal. Yogyakarta: Universias Atmajaya.

Hamzah, Andi (2011). Delik-delik tertentu (special delicten) di Dalam KUHP. Jakarta: Sinar Grafika.

Latif, Abdul dan Hasbi, Ali (2011). Politik Hukum. Jakarta: Sinar Grafika.

Arief, Barda Nawawi (2011). Bunga Rampai Kebijakan Hukum Pidana (Perkembangan Penyusunan Konsep KUHP Baru). Jakarta: Kencana Prenada Media Group.

Arief, Barda Nawawi dan Muladi (1992). Bunga Rampai Hukum Pidana. Bandung: Alumni.

Prasetyo, Teguh dan Barkatullah, Abdul Halim (2005). Politik Hukum Pidana Kajian Kebijakan Kriminalisasi dan Dekriminalisasi. Yogyakarta

Salman, Luthan (2007). Kebijakan Penal Mengenai Kriminalisasi di Bidang Keuangan. Desertasi.

Utsaman, Sabian (tt). Menuju Penegakan Hukum Responsif, Konsep Nonet dan Philip Seznick. Yogyakarta: Pustaka pelajar.

Depdikbud RI (1990). Kamus Besar Bahasa Indonesia. Jakarta: Balai Pustaka.

\section{PERATURAN PERUNDANG-UNDANGAN}

Majelis Ulama Indonesia Pusat. Keputusan Fatwa Komisi Fatwa Majelis Ulama Indonesia Nomor 287 Tahun 2001 tentang Pornografi dan Pornoaksi, 22 Agustus 2001

Undang-undang No 14 tahun 2008 Tentang Pornografi LEMBARAN NEGARA REPUBLIK INDONESIA TAHUN 2008 NOMOR 181 dan TAMBAHAN LEMBARAN NEGARA REPUBLIK INDONESIA NOMOR 4928

Risalah Sidang Paripurang DPR tentang Undang-Undang Pornografi Tanggal 30 Oktober 2008 
wikipedia.org/wiki/Undang-Undang_Pornografi\# Definisi_da n_Rancangan 